\title{
Paraton Outdoor Life, Inc. A Case Study on Reported Cash Flow and Gaps in Financial Statements
}

\author{
Prakash Deo \\ University of Houston-Downtown \\ Cathy Zishang Liu \\ University of Houston Downtown
}

Managers and analysts are trained to validate the cash balance in the balance sheet with the cash balance in the bank, and to rely on the cash flow statement rather than the income statement and the balance sheet. The purpose of this case study is to develop a case study to validate a stepped approach to understand the interaction of the various income statement and the balance sheet accounting transactions captured in the cash flow statement. The decomposition of the various components of the cash flow statements not only reveals these interactions but also helps to understand the interplay among these components of the cash flow statement. It should help both the internal and external analysts to develop a modular pathway for each accounting transaction and identify any earning warning signals about a firm's attempts to manipulate the change in the cash account.

Keywords: cash flow, income statement, balance sheet, cash balance

\section{INTRODUCTION}

On February15 ${ }^{\text {th }}$, 2016, Jeff McDonald, Chief Executive Officer (CEO) of Paraton Inc. returned to his office after a long meeting with the Interim Chief Financial Officer (CFO) and his staff and was deeply concerned about the timely publication of the $4^{\text {th }}$ quarter results and the annual report.

Paraton Inc. is a publicly-traded firm in a large city in the southern United States and has been a major national player in procurement and sale of outdoor products for the past 30 years, and each year the shareholders had earned a satisfactory rate of return on their investments via dividends and price appreciation. In June 2014, after more than 25 years with the company, the CFO Mark Johnson retired. The management team hired an executive search firm to find his replacement and hired a young and dynamic CFO, who had graduated from a well-known university. Soon thereafter, the new CFO offered the Controller, a veteran of almost 24 years, a very generous early retirement package, and brought on board his schoolmate, an aggressive and energetic manager with a razor-focused vision to bring this company into the $21^{\text {st }}$ Century, who was also known to steer subordinates to his way of thinking. On January 5, 2016, after about sixteen months with the company, both the CFO and the Controller abruptly left the firm. Until they find their replacements, McDonald and the senior management team rehired the retired CFO Johnson to assume the dual roles of interim controller and CFO. He decided to take a deep dive into the preparation of the 2015 annual report before working with the independent accounting firm. 
He hired several interns to help the firm's accounting staff verify the accounting transactions, and to meet the deadlines on various sections of the quarterly and annual reports. After a few weeks of around the clock inspection of the firm's accounting transactions of the prior two years, on February 15th, 2016, Johnson asked McDonald and his management team to meet with him and his staff. Johnson informed the senior management team that he was concerned about certain doubtful transactions on the accounting books and suggested that the team immediately schedule working meetings with the independent accounting firm. Table 1 delineates the timetable of these events.

\section{TABLE 1 TIME-TABLE OF EVENTS}

\begin{tabular}{|l|l|}
\hline \multicolumn{1}{|c|}{ Date } & \multicolumn{1}{c|}{ Event } \\
\hline June, 2014 & Mr. Johnson, CFO retired. \\
\hline August 2014 & New CFO hired. \\
\hline September, 2014 & $\begin{array}{l}\text { The new CFO offered the controller a retirement package, who accepted the } \\
\text { retirement package and left the company. }\end{array}$ \\
\hline October, 2014 & The CFO hired his schoolmate as a new controller. \\
\hline January, 2016 & The CFO and the controller left the company. \\
\hline January, 2016 & The retired CFO, Johnson was rehired as interim CFO \\
\hline January, 2016 & The CFO team initiated the preparation of the quarterly annual reports. \\
\hline February, 2016 & The CFO set up an urgent meeting with the CEO and senior management team. \\
\hline
\end{tabular}

\section{The February 15th Meeting}

During the meeting on February $15^{\text {th }}, 2016$, Johnson informed the management team that to the best of their knowledge, while the 2014 financial statements were in compliant with the GAAP accounting principles, the firm's 2015 accounting books were not, and specifically three transactions were of concern. McDonald was in shock to the best of his knowledge, there had not been any issues raised by the independent auditors he had hired since he took of the office of the CEO. Over his long career at the firm, he had always kept a vigilant eye on the income statement and the balance sheet, specifically the cash position, and did not see anything that was alarming to him. Over the 25 years while working with Johnson, McDonald had learnt some basic financial lessons about cash. He was aware that while stockholders, managers, suppliers, accountants and employees are concerned about the firm's cash flow and believe that cash flow is relatively free from manipulation. He understood that the cash flow from continuing operations is the cash flow engine of the company. This engine not only provides the cash flows to cover the cash needs of operations, but also serves as a source of internally generated cash necessary for replacement of worn-out equipment, and the promised dividend payments. Any short falls require a firm to seek funds from the capital markets. Of course, a bank statement can be forged, and the experienced accountants and/or auditors should notice it if the numbers do not match.

\section{THE 2015 ACCOUNTING BOOKS}

Under Johnson's supervision, the team of interns analyzed certain entries of all 2015 transactions and worked with other senior accounting staff members to understand and clarify issues utilizing the most recent codification of Generally Accepted Accounting Principles (GAAP). While some transactions appear to comply with the GAAP principles, the team was concerned about three transactions. Furthermore, comprehensive efforts to detect the disconnections between the transactions and the books were obviously needed. To that end, the interns isolated individual impact of each of the three transactions on the three financial statements. The information related to the pre-transaction, the transaction, and the post-transaction for the year 2015 is shown in Tables 1, 2 and 3. 


\section{The Income Statements}

The 2015 income statement in Table 2 shows the impact of the three transactions. Specifically, the net sales were up by $\$ 30 \mathrm{M}$ (see transaction \#1), and the bad-debt expense, which was part of the sales and marketing expense account, decreased by $\$ 3 \mathrm{M}$ (see transaction \#2). The interns noted that the provision for doubtful accounts in the balance sheet, which generally increases with sales, did not go up during this period. In addition, the firm had not changed its credit line policy for its customers during 2015. The depreciation expenses in the general and administrative account decreased by $\$ 7 \mathrm{M}$ (see transaction \#3). The interns learnt that the departed CFO \& controller had asked the firm's accountants to revise the useful life of the long-term assets. Upon requesting further information regarding this issue, some accountants vaguely recalled that the departed CFO and controller had mentioned that some of the assets had become obsolete due to the advances in technology. They were planning to provide backup information to justify the change in the useful life of the assets, but no one in the accounting department could locate such details from the accounting records. The interns also noted that both the bad debt and depreciation expenses were non-cash accounting entries, and as expected, the increase in sales were accompanied with the increases in cost of goods sold and income taxes. In short, assuming the income tax rate remained unchanged, the three transactions in combination, incrementally increased the net income by $\$ 18.349 \mathrm{M}$, which was a 5\% increase compared to the 2014 net income.

\section{TABLE 2 \\ ACCOUNTING BOOKS FOR PREPARATION OF THE INCOME STATEMENT ENDING DEC. 31 ${ }^{\mathrm{ST}}, 2015$ (IN THOUSANDS)}

\begin{tabular}{|c|c|c|c|}
\hline & 2015 Pre-Tran. & Tran. \# & 2015 Post-Tran. \\
\hline Net sales* & 712,575 & 1 & 742,575 \\
\hline Cost of goods sold & 390,841 & & 407,296 \\
\hline Gross profit & $\underline{321,734}$ & & $\underline{335,279}$ \\
\hline \multicolumn{4}{|l|}{ Operating expenses** } \\
\hline Sales and marketing & 78,000 & 2 & 75,000 \\
\hline General \& administrative & 182,126 & 3 & 175,126 \\
\hline Total operating expense & $\underline{260,126}$ & & 250,126 \\
\hline Income from operations & 61,608 & & 85,153 \\
\hline \multicolumn{4}{|l|}{ Other expense (Income), net } \\
\hline Interest Income & $(160)$ & & $(160)$ \\
\hline Interest expense & 2,209 & & 2,209 \\
\hline Other income, net & $(57)$ & & (57) \\
\hline Total other expense, net & 1,992 & & 1,992 \\
\hline Income before income taxes & 59,616 & & 83,161 \\
\hline Income Taxes & 13,156 & & 18,352 \\
\hline Net Income & 46,460 & & 64,809 \\
\hline
\end{tabular}

*The Net sales includes various other transactions. The difference in pre- \& post transaction are shown only for the transactions that were of concerns to the interns.

**We break down the Selling, general and administrative expenses into two components: (1) Sales and marketing, and (2) General \& administrative, to illustrate the effects of bad debt and depreciation expenses on the financial statements. 


\section{The Balance Sheets}

The balance sheet in Table 3 shows that due to the transaction \#1, the cash \& cash equivalents account increased by $\$ 30 \mathrm{M}$. Upon further inquiries, the interns learnt that the cash amount originated from a customer's payment for future products and services. At the end of 2015, the firm had not provided these merchandise or services though the management had discussed the contract intensely and had planned to deliver on their promises in the future. The firm controlled the merchandise and shipped it to a warehouse close to the customer's location. Upon booking the transaction \#2, the allowance for the doubtful account decreased by $\$ 3 \mathrm{M}$. In addition, upon booking the transaction \#3, the accumulated depreciation account was lower by $\$ 7 \mathrm{M}$. The effects of these three transactions on the balance sheet aligned with those in the income statement. Upon posting of these three transactions, the grand total of all assets showed an increase of $\$ 23.545 \mathrm{M}$. Moving on to the right-hand side of the balance sheet, the income taxes payable increased by $\$ 5.196 \mathrm{M}$. Upon further investigation, the interns discovered that the increase in the taxes payable was due to the increase in the sales and a downward adjustment to the operating expenses in the income statement. Additionally, the retained earnings showed an increase of $\$ 18.349 \mathrm{M}$, which aligned with the increase in the net income. Overall, the increase in assets due to these three transactions was in balance with the increase in the total liabilities and equity. Upon completion of their examination, the interns documented their reasons to cast doubts about these three transactions.

TABLE 3

THE BALANCE SHEET ENDING DEC. $31^{\mathrm{ST}}, 2015$ (IN THOUSANDS)

\section{Pre-Tran. $\quad \underline{\text { Tran. \# } 2015 \text { Post-Tran. }}$}

Assets

\section{Current assets}

Cash \& cash equivalents

Accounts receivable

Allowance for doubtful accounts

Inventories

Prepaid expenses

Other current assets

Total current assets

\section{Long-term Assets}

Fixed assets

Accumulated depreciation

Other assets

Total Assets

\section{Liabilities}

\section{Current liabilities}

Trade accounts payable

Accrued payroll

Other accrued liabilities

Income taxes payable

Total current liabilities

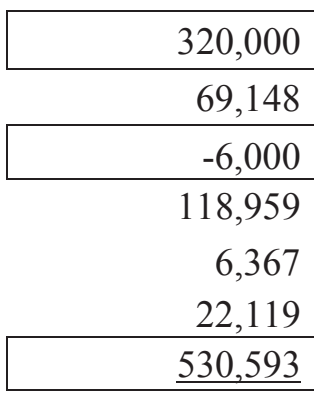

1
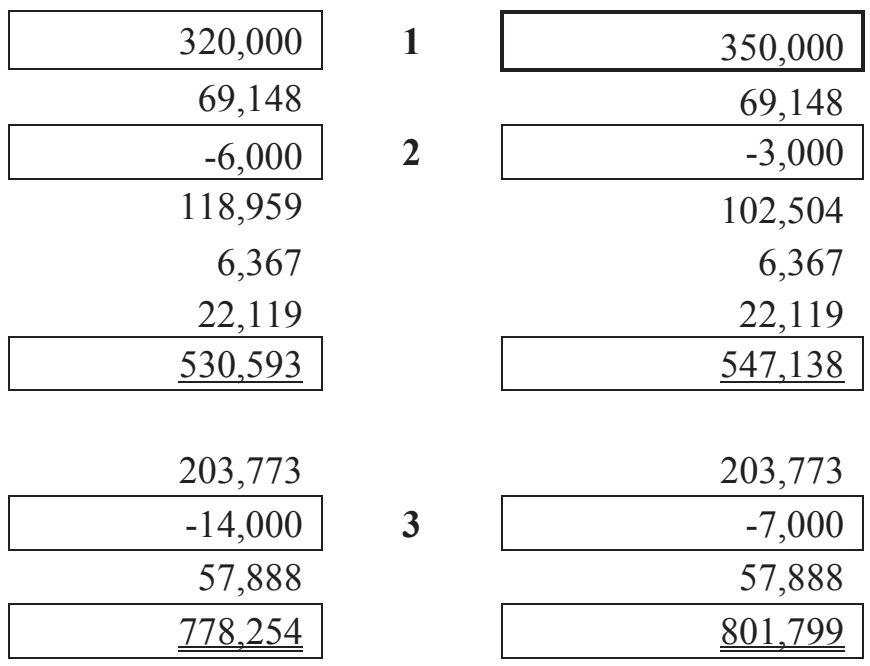

\section{2}

$\underline{\underline{547,138}}$

3

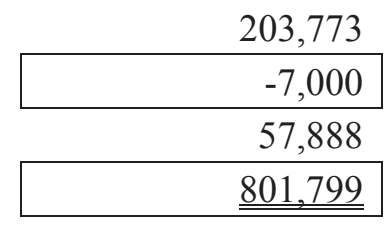

38,389

8,999

12,664

38,454

33,258

$\underline{98,506}$ 


\begin{tabular}{lrr} 
Long-term liabilities & & \\
Long-term debt & $\underline{42,240}$ & $\underline{42,240}$ \\
$\quad$ Total liabilities & $\underline{135,550}$ & $\underline{140,746}$ \\
Stockholders' equity & & 127 \\
Common stock (\$0.01 par value) & 127 & 64,006 \\
Additional paid-in capital & 64,006 & 596,920 \\
Retained earnings & 578,571 & $\underline{661,053}$ \\
$\quad$ Shareholder equity & $\underline{642,704}$ & 801,799 \\
\hline Total liabilities and equity & 778,254 &
\end{tabular}

\section{The Statement of Cash Flow}

The interns noticed that cash from operating activities increased by $\$ 30 \mathrm{M}$ See Table 4 . The firm had adopted the indirect method for the development of the change in operating cash flow for financial reporting purposes. Under this method, this increase in cash was due to the combination of the (1) change in net income (transaction \#1), (2) the provision for doubtful accounts (transaction \#2), (3) the change in depreciation expense (transaction \#3), and (4) the change in working capital. The change in working capital, in turn, reflected changes in the inventory and current liability accounts. The interns also determined that only transaction \#1 involved cash and the adjustments to the bad debt reserve and useful life of the long-term assets did not involve cash. Therefore, the increase of $\$ 30 \mathrm{M}$ in cash on the books appeared to be "reasonable" upon posting of these three transactions. Although Johnson verified the cash balance with the bank, the interns questioned the validity of the above four sources that were used to construct the change in operating cash flow.

\section{THE THREE TRANSACTIONS IN QUESTION}

\section{Details of Transaction \#1}

At the end of 2015 , the company had signed a contract and had received $\$ 30 \mathrm{M}$ in advance with the expectation of delivery of certain retail products and services by the end of 2016 . The company started to ship some of the merchandise to a warehouse it recently purchased. The new warehouse is close to the customer's geographical location. The company has full control of the merchandise during the entire 2015.

\section{Details of Transaction \#2}

The company sold its product and services on credit consistent with the existing industry practice and with the understanding that some customers may default. After the thanksgiving weekend in 2015, during their regular monthly receivables meeting, the new controller had directed one of the accounting managers to book the bad-debt expense of $\$ 3 \mathrm{M}$ instead of the estimated amount of $\$ 6 \mathrm{M}$, which was developed using the historical collection rate. The new controller justified the change for the robust growth in family spending on sports goods. He didn't mention anything regarding the firm's credit policy.

\section{Details of Transaction \#3}

The new controller of Paraton Inc. had directed the accounting manager to use a ten-year life instead of the prior years' practice of using five-year life for this class of assets, which led to the decrease in total depreciation expenses from $\$ 9.710 \mathrm{M}$ to $\$ 2.710 \mathrm{M}$ in 2015 . 
TABLE 4

THE STATEMENT OF CASH FLOW ENDING DEC. 31ST, 2015 (IN THOUSANDS)

\section{Cash flow from operating (in thousands)}

Net income

\section{Pre-Tran.}

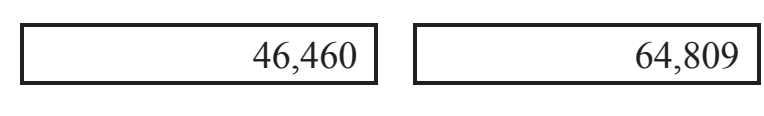

Adjustments to reconcile net income to net cash provided (used) by operating activities:

Depreciation

Provision for doubtful accounts, net

Changes in operating assets and liabilities

Trade accounts receivable

Inventories, net

Prepaid expenses and other current assets

Trade accounts payable

Accrued payroll

Other accrued liabilities

Income tax payable

\section{Cash flow from investing activities}

PP\&E Purchases

Proceeds from sale of assets

\section{Cash flow from financing activities}

Proceeds from issuance of stock

Proceeds from mortgage loan

\section{Net Change in Cash}

Beginning Cash

Ending Cash
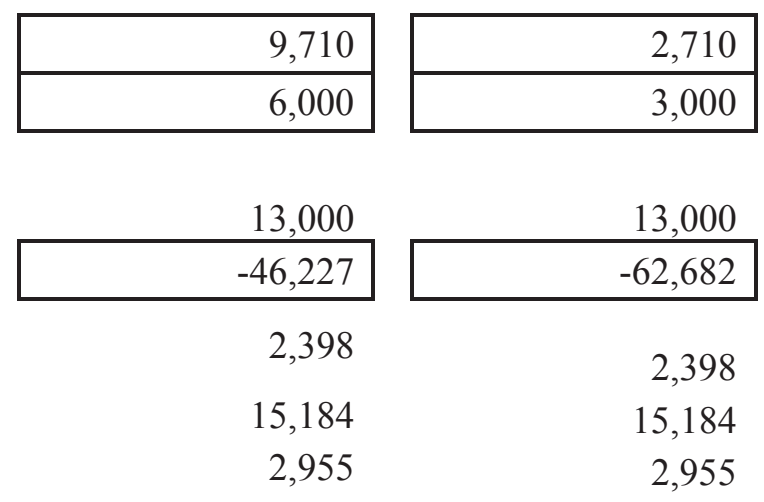

$\underline{5,000}$

10,196

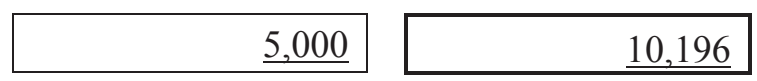

\begin{tabular}{|c|c|}
\hline 0 & 0 \\
\hline 0 & 0 \\
\hline 0 & 0 \\
\hline 0 & 0 \\
\hline 116,138 & 146,138 \\
\hline 203,862 & 203,862 \\
\hline 320,000 & 350,000 \\
\hline
\end{tabular}

Questions

1. Assuming the role of the interns, summarize the list of issues.

- Discuss the pros and cons for each issue

- Prepare the correct set of transactions.

2. What hurdles might the interns encounter during their presentation?

3. Assuming McDonald adopts the recommendation, what are the appropriate next steps?

- What are the problems in adopting and implementing the recommended solutions?

4. What do you think transpired at the presentation? What did the senior management team decide to do? Why? 


\section{TEACHING NOTES (ANSWERS TO THE QUESTIONS)}

Paraton Inc. is a fictitious publicly-traded firm in a large city in the southern United States and is a major national player in wholesale and retail outdoor products. This case study should help students develop an understanding of critical financial reporting issues related to cash flow and accrual accounting. The case is suitable for both graduate and undergraduate students and may be used as a supplement to a financial accounting textbook.

This assignment requires students to examine a firm's accounting books over prior to and post of the transaction period. The students assume the roles of interns in the accounting department. To that end, they conduct an internal audit of business transactions and the accounting books immediately after the departure of the firm's CFO and Controller. First, the students identify errors in recording transactions on the books based on accrual accounting, and then their attention is drawn to the sinuous relations of these errors, which are constructed and recorded in the financial statements including the income statement, balance sheet, and statement of cash flow. Next, the students understand how these errors carry over from one financial statement to another. Finally, the students compare and contrast the GAAP compliant and non-compliant accounts, which originate from the differences in the accounts of the financial statements over a reporting period. After completion of their analysis, the interns present their findings to the CFO and management team.

Although Paraton Outdoor Life, Inc. is a fictitious firm, we have developed the accounting records based on operations and accounting practices of a real firm that operates in a wholesale and retail outdoor products industry. In short, the financial statements are developed based on actual transactions, providing the students with the opportunities to learn in a realistic environment. The students also learn realitybased accrual accounting and understand how firms may engage in the financial numbers game during the development of the financial statements including the statement of cash flow. While they perform the reconciliations among the cash flow and other accrual accounting components, the students will also practice the critical thinking skills as they detect the disconnects among the transactions and the balances of the accounts of financial statements.

Question 1. Assuming the roles of the interns summarize the list of issues.

- Discuss the pros and cons for each issue

- Prepare the correct set of transactions.

Answer: The FASB guidelines recommend that the revenue should be recognized and recorded upon completion of the earnings process and the exchange of services or goods or an asset such as cash. However, managers may not follow these guidelines, and instead recognize the revenues on the books when future services are still outstanding or in presence of significant uncertainty. They may ship goods prior to the finalization of the sale and record the revenues in the books though there are may be significant chances that the customers may not pay, or they may return the goods. The use of percentageof-completion method even with an existence of a long-term contract is an aggressive accounting practice. A transfer of an ownership to the buyer requires the buyers to assume the risks and gain the benefits of ownership. If a sale is contingent upon uncertainty in a buyer's financing situation, then the seller should not record revenues related to this transaction. If a transaction involves a buyer's payment upon certain contingencies, then the seller should not record revenues until the resolution of these contingencies. When the future services from the seller are expected, the seller should recognize it as a liability. That is, any firm that receives a significant up-front fees or payment should not record the entire amount as revenues, which are also known as front-end loading. Instead, the recognition of the revenues should follow the GAAP guidelines. The following scenario illustrates the impact of accounting transactions related to the timing of recognition of revenue on cash flow.

\section{Transaction \#1}

If a firm receives $\$ 30$ million with an expectation of completion of future products and services, then the Non-GAAP accounting practices are: 
Transaction \#1 (Non-GAAP)

$\begin{array}{ll}\text { Increase: Cash } & \$ 30 \mathrm{M} \\ \text { Increase: Sales } & \$ 30 \mathrm{M}\end{array}$

A firm may record the transaction as shown above and overstate the net income via overstating the sales and understating the liabilities. However, the GAAP accounting practices for this transaction are:

$\begin{array}{ll}\text { Transaction } \# 1(G A A P) & \\ \text { Increase: Cash } & \$ 30 \mathrm{M} \\ \text { Increase: Unearned revenue } & \$ 30 \mathrm{M}\end{array}$

Note: the cash account is an asset, and the unearned revenue is a liability. Upon the completion of the service, a firm should convert the unearned revenue into revenue.

The use of Non-GAAP and GAAP in recording the transactions will have distinct impacts on financial statements as shown below:

TABLE 5

SUMMARY OF IMPACT ON FINANCIAL STATEMENTS FOR TRANSACTION \# 1

\begin{tabular}{|c|c|c|c|c|c|c|c|}
\hline \multirow[t]{2}{*}{ Transaction \#1 } & \multicolumn{2}{|c|}{ Income Statement } & \multicolumn{2}{|l|}{ Balance Sheet } & \multicolumn{3}{|c|}{ Statement of Cash Flows } \\
\hline & Rev & $-\operatorname{Exp}=$ & Asset $=$ Liab + & Equ & OCF & $-\mathrm{ICF}+\mathrm{FCF}=$ & $\mathrm{NCF}$ \\
\hline Non-GAAP & $+30 \mathrm{M}$ & $+30 \mathrm{M}$ & $+30 \mathrm{M}$ & $+30 \mathrm{M}$ & $+30 \mathrm{M}$ & & $+30 \mathrm{M}$ \\
\hline GAAP & & & $+30 \mathrm{M}$ & & $+30 \mathrm{M}$ & & $+30 \mathrm{M}$ \\
\hline
\end{tabular}

Recording the transactions as Non-GAAP and GAAP result in the same amount of OCF, but further examination shows a different picture. Comparing the two transactions, we observe that the use of NonGAAP accounting overstates revenue and therefore net income by $\$ 30 \mathrm{M}$ in the income statement. It also understates liability by $\$ 30 \mathrm{M}$ and therefore, overstates equity by $\$ 30 \mathrm{M}$ in the balance sheet. In addition, there are flaws in the ensuing construct of operating cash flows in the statement of cash flow. That is, while the total amount of operating cash flows utilizing either the Non-GAAP or the GAAP remain the same, the OCF in Non-GAAP transaction comes from the overstatement of net Income, when in fact it should come from an increase in non-cash current liability (i.e., unearned revenue). This result is because $\mathrm{OCF}=\mathrm{NI}+\mathrm{DEP}-$ Change in Net Operating Working Capital. The Non-GAAP overstates the first component in deriving OCF (i.e., net income) by $\$ 30$ milliion and understates the third component (i.e., current liability) by $\$ 30$ million. Thus, users of financial statements can be misled by the erroneous sources of operating cash flows, which in turn, may lead to misinterpretation about the sustainability of its earnings from operating activities.

\section{Transaction \#2}

The GAAP guidelines state that if a customer is in financial distress, then the accountants should record receivables at their net realization value. The amount of default is treated as a bad debt expense. On the balance sheet, a firm reports the account receivables balance, and allowance of doubtful accounts, the difference is net realizable value representing the expected collection amount in the future from credit sales. On the income statement, a firm should report bad debt expense. This expected loss from collection will reduce the net income.

The allowance for uncollectible is a contra-asset account. The net realization value is an asset. Managers may underestimate the default rate, which may lead to an underestimation of the bad debt expense and an overstatement of assets and net income. In the case below, assume a company estimates its bad-debt expense of $\$ 3 \mathrm{M}$ instead of $\$ 6 \mathrm{M}$. Then the accounting entries are: 
Transaction \#2 (Non-GAAP)

Increase: Bad Debt Expense

$\$ 3 \mathrm{M}$

Increase: Allowance for Doubtful Accounts $\$ 3 \mathrm{M}$

Transaction \#2 (Non-GAAP)

Increase: Bad Debt Expense

$\$ 6 \mathrm{M}$

Increase: Allowance for Doubtful Accounts $\quad \$ 6 \mathrm{M}$

The use of Non-GAAP and GAAP in recording the transactions will have distinct impacts on financial statements as shown below:

TABLE 6

SUMMARY OF IMPACT ON FINANCIAL STATEMENTS FOR TRANSACTION \# 2

\begin{tabular}{|l|l|ll|l|l|}
\hline Transaction \#2 & \multicolumn{2}{|l|}{$\begin{array}{l}\text { Income Statement } \\
\text { Rev }- \text { Exp }=\text { NI }\end{array}$} & $\begin{array}{l}\text { Balance Sheet } \\
\text { Asset }=\text { Lia }+ \text { Equ }\end{array}$ & $\begin{array}{l}\text { Statement of Cash Flows } \\
\text { OCF } \\
\text { NCF }\end{array}$ \\
\hline Non-GAAP & $-3 \mathrm{M}=-3 \mathrm{M}$ & $-3 \mathrm{M}$ & $-3 \mathrm{M}$ & $-3 \mathrm{M}+3 \mathrm{M}$ & 0 \\
\hline GAAP & $-6 \mathrm{M}=-6 \mathrm{M}$ & $-6 \mathrm{M}$ & $-6 \mathrm{M}$ & $-6 \mathrm{M}+6 \mathrm{M}$ & 0 \\
\hline
\end{tabular}

Upon comparison of the Non-GAAP and GAAP for the entries in transaction \#2, we observe that Non-GAAP transaction understates expenses, and thereby overstates the net income by $\$ 3 \mathrm{M}$ in the income statement. It also overstates both assets and equity by $\$ 3 \mathrm{M}$ in the balance sheet. This muddles up the components of operating cash flows, though the total amount of operating cash flows is not affected. In the calculation of the OCF, the first component is NI. Therefore, in the Non-GAAP transaction \#2, the OCF will go down by $\$ 3 \mathrm{M}$. The third component of OCF involves the change in net operating working capital. Since the account receivable decreases by $\$ 3 \mathrm{M}$, the net change in operating working capital will go up by $\$ 3 \mathrm{M}$. In summary, the first and third components of OCF cancel each other out. The correct construct of OCF should reflect accounting entries of \$6M rather than $\$ 3 \mathrm{M}$ for both the first and third components. In this case, the net change in OCF masks the impact on earnings. Therefore, financial analysts and forensic accountants must examine the impact on all financial statements, and not just the income statement and the balance sheet.

\section{Transaction \#3}

The decisions involving the length of period for amortization of leasehold improvements, writing off any impaired assets, and a decision to capitalize or expense is made at management's discretion and can influence short-run profit by moving current expenses in the future periods. A firm derives benefits from the use of assets, such as inventories sold, and property, plant, and equipment deployed in the business. A portion of the asset is converted into an expense account in a manner or a rate similar to the derivation of the benefits. Upon sale, the inventory is moved into the cost of goods sold expense category. Finally, the deterioration in long-term asset value (which does not directly relate to the production process or cost of goods sold) is reflected in depreciation expense and is reported in selling, general and administrative expenses.

The following example illustrates the transactions related to the decision to change the length of the period for depreciation of an asset. The depreciation of equipment over a ten versus five-year period will lead to the following accounting records: 
Transaction \#3 (Non-GAAP)

Under aggressive accounting practices, the company will select a ten-year useful life of the equipment.

Increase: Depreciation Expense

$\$ 7 \mathrm{M}$

Increase: Accumulated Depreciation

$\$ 7 \mathrm{M}$

\section{Transaction \#3 (GAAP)}

Under conservative accounting practices, the company will select a

five-year useful life of the equipment

Increase: Depreciation Expense

$\$ 14 \mathrm{M}$

Increase: Accumulated Depreciation

$\$ 14 \mathrm{M}$

The use of Non-GAAP and GAAP in recording the transactions will have distinct impacts on financial statements as shown below:

TABLE 7

SUMMARY OF IMPACT ON FINANCIAL STATEMENTS FOR TRANSACTION \# 3

\begin{tabular}{|c|c|c|c|c|c|c|}
\hline \multirow[t]{2}{*}{ Transaction \#3 } & Income Statement & \multicolumn{3}{|c|}{ Balance Sheet } & \multicolumn{2}{|c|}{ Statement of Cash Flows } \\
\hline & Rev $-\operatorname{Exp}=$ & Asset $=$ & $\operatorname{Lia}+$ & Equ & OCF & $=\mathrm{NCF}$ \\
\hline Non-GAAP & $-7 \mathrm{M}=$ & $-7 \mathrm{M}$ & & $-7 \mathrm{M}$ & $-7 M+7 M$ & 0 \\
\hline GAAP & $-14 \mathrm{M}=-14 \mathrm{M}$ & $-14 \mathrm{M}$ & & $-14 \mathrm{M}$ & $-14 \mathrm{M}+14 \mathrm{M}$ & 0 \\
\hline
\end{tabular}

The difference arising from non-GAAP and GAAP entries for transaction \#3 on the financial statements is obvious. The non-GAAP transaction understates operating expense and therefore overstates net income by $\$ 7$ million in the income statement. It also overstates the book value of assets and the equity each by $\$ 7 \mathrm{M}$ in the balance sheet. Furthermore, the lower rate of depreciation in transaction \#3 leads to higher book values of PP\&E and equity, and it boosts the net profit due to lower depreciation expenses. This approach can lead to obsolete equipment in the long-run, in particular, in an industry with a rapid change in technology. Moreover, the components to reconcile operating cash flows are muddled up, as depreciation is a non-cash expense, and has no impact on the statement of cash flow. The nonGAAP transaction overstates the first component (i.e., NI) in the calculation of operating activities (OCF). The second component of OCF is the depreciation expense, and it is understated. The offsetting entries cancel each other out and have no impact on the calculation of the net cash flow, even though the values of the individual component are erroneous. However, the non-GAAP transaction creates the perception that the firm is earning higher income, and that it is managing its assets efficiently as it reports a lower depreciation expense. The tables 8, 9, and 10 illustrate the impacts of exercising NON-GAAP versus GAAP on accounting books. 
TABLE 8

THE INCOME STATEMENT USING NON-GAAP VERSUS GAAP

\begin{tabular}{|c|c|c|c|c|c|c|}
\hline \multirow{2}{*}{$\begin{array}{l}\text { (in thousands) } \\
\text { The income statement }\end{array}$} & \multirow{2}{*}{$\frac{\mathbf{2 0 1 5}}{\text { Pre-Tran }}$} & \multicolumn{2}{|c|}{ Non-GAAP } & \multirow[t]{2}{*}{$\#$} & \multirow{2}{*}{ Tran } & \multirow{2}{*}{$\begin{array}{l}\text { GAAP } \\
\text { Post }\end{array}$} \\
\hline & & Tran & Post & & & \\
\hline Net sales & 712,575 & 30,000 & 742,575 & 1 & & 712,575 \\
\hline Cost of goods sold & 390,841 & & 407,296 * & & & 390,841 * \\
\hline Gross profit & $\underline{321,734}$ & & 335,279 & & & 321,734 \\
\hline \multicolumn{7}{|l|}{ Operating expenses } \\
\hline Sales and marketing & 78,000 & 75,000 & 75,000 & 2 & 78,000 & 78,000 \\
\hline General \& administrative & 182,126 & 175,126 & 175,126 & 3 & 182,126 & 182,126 \\
\hline Total operating exps. & 260,126 & & 250,126 & & & 260,126 \\
\hline Income from operations & $\underline{61,608}$ & & 85,153 & & & $\overline{260,126}$ \\
\hline \multicolumn{7}{|l|}{ Other expense (Income), net } \\
\hline Interest Income & (160) & & $(160)$ & & & $(160)$ \\
\hline Interest expense & 2,209 & & 2,209 & & & 2,209 \\
\hline Other income, net & (57) & & (57) & & & (57) \\
\hline Total other expense, $n \epsilon$ & 1,992 & & 1,992 & & & 1,992 \\
\hline Income before income tax & 59,616 & & 83,161 & & & 258,134 \\
\hline Income Taxes & 13,156 & & 18,352 & & & 13,156 \\
\hline Net Income & 46,460 & & 64,809 & & & $\underline{46,460}$ \\
\hline
\end{tabular}

*The cost of goods sold varies due to the differences in sales.

** The income tax expenses vary due to the difference in incomes from operations.

Analysts and managers use the accounting statement of cash flow to forecast a firm's cash position. The cash flow statement is more reliable than income statement or balance sheet data as the income statement contains many arbitrary noncash allocations, and the balance sheet data are static-measuring a single point in time. On the other hand, the cash flow statement represents activities for a continuous period and includes the changes in other financial statements, and nets out the bookkeeping artifice to derive cash from operations to validate a firm as an on-going concern with funds available for investment. Auditors use the cash flow statement to verify balance sheet and income statement accounts and to trace common items to the cash flow statement. Auditors can strengthen corporate governance by keeping an eye out for red flags and fraud signals such as unusual or unexpected fluctuations in financial statement relationships.

According to the statement of financial accounting standard No. 95, "Statements of Cash Flows," the information in the statement, if used with information in other financial statements, can help investors, creditors, and others to assess an entity's ability to meet its obligations and to pay dividends, and determine its needs for external financing during the period.

The statement of cash flow provides key information regarding liquidity, solvency and financial flexibility. Specifically, cash generated from operations should receive more emphasis in financial analysis. The timing of cash inflows and outflows help determine the prospects of future cash flows.

The statement of cash flows in the annual reports delineates the reconciliation between net income and cash flows from operating activities. The net income includes both cash- and non-cash inflows and outflows, and therefore it is adjusted to reflect any noncash impact from operating activities. The cash account is exceedingly hard to cheat, as at the end of the day there is a bank statement that reflects a certain amount of cash, which should match with the cash balance amount in the cash flow statement. 
TABLE 9

THE BALANCE SHEET USING NON-GAAP VERSUS GAAP

\begin{tabular}{|c|c|c|c|c|c|c|c|c|}
\hline \multirow{2}{*}{$\begin{array}{l}\text { (in thousands) } \\
\text { The balance sheet }\end{array}$} & \multirow{2}{*}{$\frac{2015}{\text { Pre-Tran }}$} & \multicolumn{2}{|c|}{ Non-GAAP } & & \multirow[t]{2}{*}{$\#$} & \multirow{2}{*}{ Tran } & \multirow{2}{*}{$\begin{array}{l}\text { GAAP } \\
\text { Post }\end{array}$} & \\
\hline & & Tran & Post & & & & & \\
\hline \\
\hline \multicolumn{9}{|l|}{ Current assets } \\
\hline Cash \& cash equivalents & 320,000 & 30,000 & 350,000 & & 1 & 30,000 & 350,000 & \\
\hline Accounts receivable & 69,148 & & 69,148 & & & & 69,148 & \\
\hline Allowance for doubtful accounts & $-6,000$ & $-3,000$ & $-3,000$ & & 2 & $-6,000$ & $-6,000$ & \\
\hline Inventories & 118,959 & & 102,504 & & & & 118,959 & * \\
\hline Prepaid epenses & 6,367 & & 6,367 & & & & 6,367 & \\
\hline Other current assets & 22,119 & & 22,119 & & & & 22,119 & \\
\hline Total current assets & $\underline{530,593}$ & & 547,138 & * & & & 560,593 & \\
\hline \multicolumn{9}{|l|}{ Long-term Assets } \\
\hline Fixed assets & 203,773 & & 203,773 & & & & 203,773 & \\
\hline Accumulated depreciation & $-14,000$ & $-7,000$ & $-7,000$ & & 3 & $-14,000$ & $-14,000$ & \\
\hline Other assets & 57,888 & & 57,888 & & & & 57,888 & \\
\hline Total Assets & $\underline{\underline{778,254}}$ & & $\underline{\underline{801,799}}$ & & & & $\underline{\underline{808,254}}$ & \\
\hline \multicolumn{9}{|l|}{ Liabilities } \\
\hline \multicolumn{9}{|l|}{ Current liabilities } \\
\hline Trade accounts payable & 38,389 & & 38,389 & & & & 38,389 & \\
\hline Accrued payroll & 8,999 & & 8,999 & & & & 8,999 & \\
\hline Other accrued liabilities & 12,664 & & 12,664 & ** & & 30,000 & 42,664 & $* *$ \\
\hline Income taxes payable & 33,258 & & 38,454 & *** & & & 33,258 & $* * *$ \\
\hline Total current liabilities & 93,310 & & 98,506 & & & & 123,310 & \\
\hline \multicolumn{9}{|l|}{ Long-term liabilities } \\
\hline Long-term debt & 42,240 & & 42,240 & & & & 42,240 & \\
\hline Total liabilities & 135,550 & & 140,746 & & & & 165,550 & \\
\hline \multicolumn{9}{|l|}{ Stockholders' equity } \\
\hline Common stock ( $\$ 0.01$ par value) & 127 & & 127 & & & & 127 & \\
\hline Additional paid-in capital & 64,006 & & 64,006 & & & & 64,006 & \\
\hline Retained earnings & 578,571 & & 596,920 & & & & 578,571 & \\
\hline Shareholder equity & 642,704 & & $\underline{661,053}$ & & & & 642,704 & \\
\hline Total liabilities and equity & $\underline{\underline{778,254}}$ & & $\underline{\underline{801,799}}$ & **** & & & $\underline{\underline{808,254}} *$ & $* * * *$ \\
\hline
\end{tabular}


TABLE 10

THE STATEMENT OF CASH FLOW USING NON-GAAP VERSUS GAAP

\begin{tabular}{|c|c|c|c|c|c|c|c|}
\hline \multirow{2}{*}{$\begin{array}{l}\text { (in thousands) } \\
\text { The CF statement }\end{array}$} & \multirow{2}{*}{$\frac{2015}{\text { Pre-Tran }}$} & \multicolumn{2}{|c|}{ Non-GAAP } & & \multirow[b]{2}{*}{ \# } & & \multirow{2}{*}{$\begin{array}{l}\text { GAAP } \\
\text { Post }\end{array}$} \\
\hline & & Tran & Post & & & & \\
\hline \multicolumn{8}{|l|}{ Cash flow from operating activities } \\
\hline Net income & 46,460 & & 64,809 & ]* & 1 & & 46,460 \\
\hline \multicolumn{8}{|c|}{ Adjustments to reconcile net income to net cash provided (used) by operating activities: } \\
\hline Depreciation & 9,710 & $-7,000$ & 2,710 & & 3 & 9,710 & 9,710 \\
\hline Provision for doubtful accounts, net & 6,000 & $-3,000$ & 3,000 & & 2 & 6,000 & 6,000 \\
\hline \multicolumn{8}{|l|}{ Changes in operating assets and liabilities } \\
\hline Trade accounts receivable & 13,000 & & 13,000 & & & & 13,000 \\
\hline Inventories, net & $-46,227$ & & $-62,682$ & ** & & & $-46,227$ \\
\hline Prepaid expenses and other current assets & 2,398 & & 2,398 & & & & 2,398 \\
\hline Trade accounts payable & 15,184 & & 15,184 & & & & 15,184 \\
\hline Accrued payroll & 2,955 & & 2,955 & & & & 2,955 \\
\hline Other accrued liabilities & 0 & & 0 & $* * *$ & & & 30,000 \\
\hline Income tax payables & $\underline{5,000}$ & & 10,196 & $* * * *$ & & & 5,000 \\
\hline \multicolumn{8}{|l|}{ Cash flow from investing activities } \\
\hline PP\&E Purchases & 0 & & 0 & & & & 0 \\
\hline Proceeds from sale of assets & 0 & & 0 & & & & 0 \\
\hline \multicolumn{8}{|l|}{ Cash flow from financing activities } \\
\hline Proceeds from issurance of stock & 0 & & 0 & & & & 0 \\
\hline Proceeds from mortgage loan & 0 & & 0 & & & & 0 \\
\hline Net Change in Cash & 116,138 & & 146,138 & & & & 146,138 \\
\hline Beginning Cash & 203,862 & & 203,862 & & & & 203,862 \\
\hline Ending Cash & 320,000 & & 350,000 & & & & 350,000 \\
\hline \multicolumn{8}{|c|}{$\begin{array}{l}\text { * The non-GAAP practice was erroneously recorded prepayment from customers as sales which leads to an increase } \\
\text { in net income. } \\
* * \text { The change in inventories is obtained by comparing the inventories in } 2015 \text { with those in } 2014 \text {. Instructors should } \\
\text { provide the information of change in inventories to students. } \\
* * * \text { The other accrued liabilities reflect the unearned revenue account. It increases by } \$ 30 \mathrm{M} \text { upon the customers' } \\
\text { pre-payment to the firm. It became } 0 \text { under the Non-GAAP method as the firm did not recognize it as a liability. } \\
\text { ***The change in income tax payables is obtained by comparison of the income tax payables in } 2015 \& 2014 .\end{array}$} \\
\hline
\end{tabular}

However, the management could muddle the components in constructing the cash flow from operating activities and paint a rosy picture of the firm's operating and core competitive advantages than it is.

\section{DISCUSSION OF CASH FLOW WITH STUDENT PARTICIPATION}

The cash flow statement is not impossible to cheat, but it requires some special efforts by the accountants, auditors, and management. Therefore, the analysts and the investors need to be careful about interpreting the cash balance in the cash flow statement. They need to check all flows in and out as well as the components of the cash flow from operating activities to evaluate and predict a firm's performance. 
They should ask themselves, "Do these flows make sense? How do these flows relate to the prior period, and why the differences, if any? How does the component of cash flows relate to each other?"

Question \# 2: What hurdles the team members may encounter during their presentation?

Answer: Some participants may question why they did not raise these issues during the tenure of the young CFO, who had just left. The issues of hierarchy and job security seems to have played a role. The issues of management oversights and the role of independent auditors are the key factors in avoiding such issues in the future. The override of the departed CFO \& controllers over the accounting employees and the role of the audit committee should be discussed here.

Question \# 3. Assuming Mr. McDonald adopts the recommendation, what are the appropriate next steps? Answer: The next step should be to inform the audit committee and the Board of Directors. The legal department should investigate any legal action against the departed controller and the CFO Concerning due diligence failures and possible management override issues. Finally, the CFO needs to set up a meeting with their independent accounting firm as soon as possible.

Question \# 4: What are the problems in adopting and implementing the recommended solutions?

Answer: The firm needs to put in place a process under the watchful eyes of its audit committee of its board of directors. It also needs to enhance internal controls and governance.

Question \# 5. What do you think transpired at the presentation?

Answer: Surprisingly, the team's presentation was well-received. There were many questions asked to ensure that suggested corrections were consistent with GAAP.

\section{IMPLICATIONS}

The authors have developed a case study to validate the usefulness of decomposing the components of the cash flow statement. Investors, analysts and the managers of corporations should not rely only on the financial information in the balance sheet and the income statement but need to use these two statements in conjunction with the cash flow statement. In addition, to gaining understanding of the net change in cash, the cash flow statement itself needs to be dissected to study the interaction of the components of the income statement and the changes in the balance sheet accounts as well as the interaction among the various sections of the cash flow statement.

\section{RECOMMENDATIONS FOR FUTURE RESEARCH}

The methodology developed in this case study should pave a path for researchers to develop stepped modules to analyze the components of the cash flow statement. It should help both the internal and external analysts to develop a modular pathway for each accounting transaction and identify any earning warning signals about a firm's attempts to manipulate the change in cash account.

\section{CONCLUSIONS}

The authors have developed a case study to validate a stepped approach for understanding the interaction of the various income statement and the balance sheet accounting transactions, which are captured in the cash flow statement. The decomposition of the various components of the cash flow statements not only reveals these interactions but also helps to understand the interplay among these components of the cash flow statement. Analysts should not only validate the cash balance in the balance sheet with the actual cash balance in the bank but also analyze carefully the development of this cash balance. And, an in-depth understanding of the GAAP is the key to such an endeavor. We have 
demonstrated with the use of a case study approach the various linkages in the generation of the cash balance in a meaningful manner to facilitate the learning process.

\section{REFERENCES}

Bahnson P. R., Miller P. B., \& Budge B. P. (1996). Non-Articulation in Cash Flow Statements and Implications for Education, Research and Practice. Accounting Horizons, 10(4), 1-15.

Brahmasrene, T., Strupeck, D. D., \& Whitten, D. (2004, October). Examining Preferences in Cash Flow Statement Format. The CPA Journal, 74, 58-60.

Broome, O.W. (2004). Statement of Cash Flows: Time for Change! Financial Analysts Journal, 60(2), $16-22$.

Cheng, C. S. A., \& Hollie, D. (2008). Do Core and Non-Core Cash Flows from Operations Persist Differentially in Predicting Future Cash Flows? Review of Quantitative Finance and Accounting, 31(1), 29-53.

Clinch, G., Sindhu, B., \& Sin, S. (2002). The Usefulness of Direct and Indirect Cash Flow Disclosures. Review of Accounting Studies, 7, 383-404.

Drtina R. E., \& Largay, J. A., III. (1985). Pitfalls in Calculating Cash Flow from Operations. The Accounting Review, LX(2), 314 - 326.

Foster, T. W., III., McNelis, L. K., \& Smith, W. L. (2012). The Statement of Cash Flows: An Indirect to Direct Conversion Tool to Enhance User Understanding and Analysis. Journal of Accounting and Finance, 12(2), 94-119.

Hagstrom, R. G., Jr. (1994). The Warren Buffett Way. John Wiley \& Sons, Inc., p 83.

Krishnan, G. V., \& Largay, J. A., III. (2000). The Predictive Ability of Direct Method Cash Flow Information. Journal of Business Finance \& Accounting, 27(1 \& 2), 215 - 245.

Miller, P. B. W., \& Bahnson, P.R. (2002). Fast Tract to Direct Cash Flow Reporting. Strategic Finance, 83(8), 51-57.

Orpurt, S. F., \& Zang, Y. (2009). Do Direct Cash Flow Disclosures Help Predict Future Operating Cash Flows and Earnings? The Accounting Review, 84(3), 893 -935.

Romero, S., \& Berenson, A. (2002, June 26). WorldCom Says It Hid Expenses, Inflating cash flow $\$ 3.8$ billion. New York Times.

Sender, H. (2002, May 8). Cash Flow? It Isn't Always What It Seems. Wall Street Journal, Eastern Edition, New York. N.Y.

Statement of Cash Flows. (1987, November). Statement of Financial Accounting Standards No. 95, Financial Accounting Standards Board, CT. 